\title{
Characterization, Antimicrobial and Antioxidant Evaluation of Biofabricated Silver Nanoparticles from Endophytic Pantoea anthophila
}

\author{
C. Nirmala ${ }^{1}$ (D) $\cdot$ M. Sridevi ${ }^{1}$ (D)
}

Received: 3 February 2021 / Accepted: 15 March 2021 / Published online: 29 March 2021

(c) The Author(s), under exclusive licence to Springer Science+Business Media, LLC, part of Springer Nature 2021

\begin{abstract}
Endophyte mediated nanoparticles fabrication were emerging as a new frontier in nanomedicines that produce high biocompatible and functionalized silver nanoparticles. In this study, silver nanoparticles were successfully biosynthesized from the extracellular extract of endophytic bacterium Pantoea anthophila isolated from the stem of Waltheria indica for the first time. The synthesized nanoparticles showed a strong absorption band at $410 \mathrm{~nm}$ in the UV-Visible range. The dynamic light scattering and zeta potential analysis indicated that the average particle size was $16 \mathrm{~nm}$ at $5.30 \mathrm{mV}$. FTIR spectrum displayed the presence of various functional groups at $3423.65,1633.71,1022.27,607.58 \mathrm{~cm}^{-1}$ that stabilised the nanoparticle. X-ray diffraction peaks were conferred to 100, 200, 220 and 311 planes of a face centred cubic structure. TEM and SEM micrograph revealed the spherical-shaped, polycrystalline nature with the presence of elemental silver analysed by EDAX. Selected area electron diffraction also confirms the orientation of silver nanoparticles with X-ray diffraction analysis. Antimicrobial activity against 10 different human pathogenic bacteria and fungi showed a broad spectrum inhibition against both Gram-positive and Gram-negative bacteria. Among the bacterial pathogens, B. Subtilis exhibited low activity compared to other pathogens. C. albicans was greatly controlled than other fungal species. A strong free radical scavenging activity of silver nanoparticles with $\mathrm{IC}_{50}$ values $31.29 \pm 0.73,19.83 \pm 1.57,35.64 \pm 0.94,42.07 \pm 1.30,29.70 \pm 2.26,29.10 \pm 0.82,36.80 \pm 0.63 \mu \mathrm{g} / \mathrm{ml}$ was obtained in different antioxidant assays that were comparable to the reference. The study suggests that the silver nanoparticles can be biosynthesized from endophytic $P$. anthophila metabolites with significant therapeutic potential. With proper validation, the biosynthesized silver nanoparticles can be developed as a promising antiviral and anticancer drug candidate.
\end{abstract}

Keywords Pantoea anthophila . Endophytic bacterium $\cdot$ Silver nanoparticles $\cdot$ Characterisation $\cdot$ Antimicrobial activity $\cdot$ Antioxidant activity

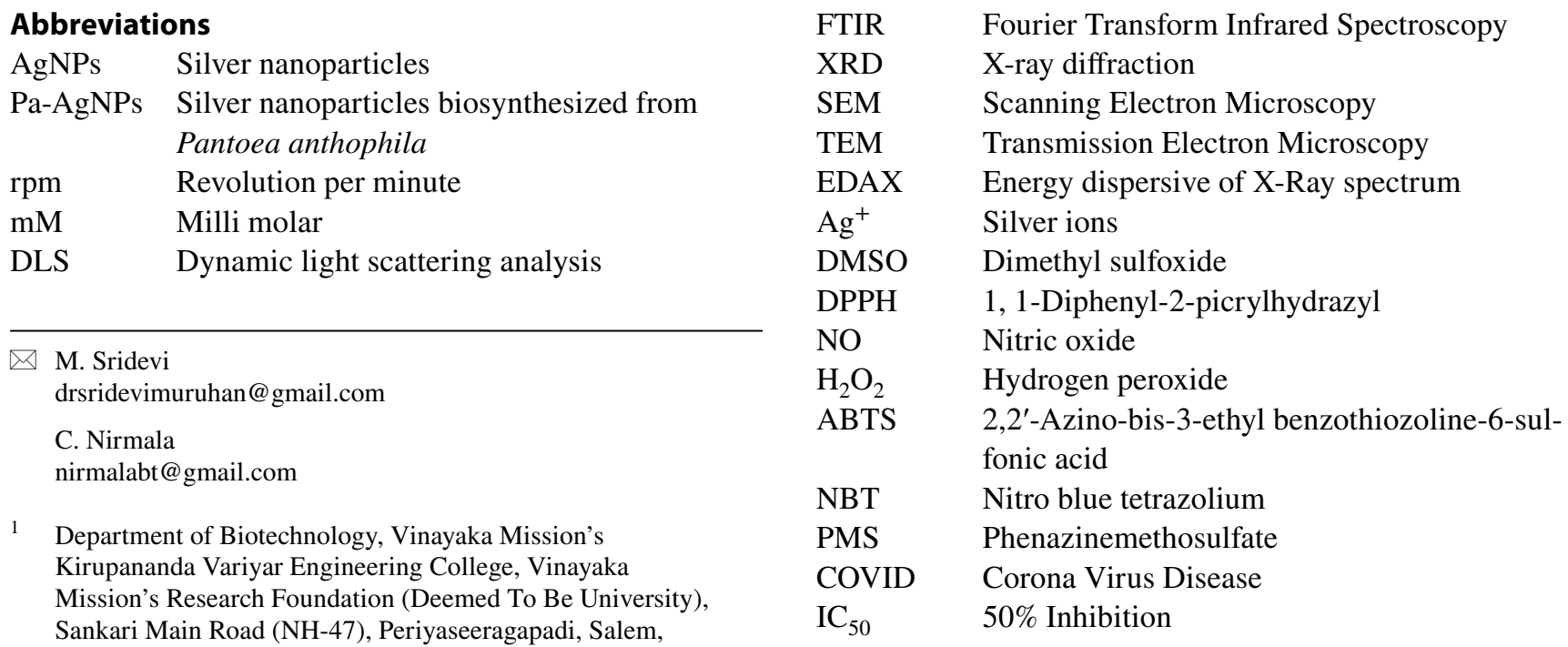




\section{Introduction}

The potential of human viral and bacterial pathogens causing diseases is rising alarmingly in recent years. The lethal condition caused by these etiological agents leads to a high death mortality rate. Scientific studies also proved that many of these infections trigger the production of reactive oxygen (ROS) and nitrogen species that can cause tissue damage resulting in inflammation. As a consequence, there is an increase in the risk of harmful diseases like acute lung injury, aging, acute renal failure, cardiovascular diseases, diabetes, neurodegenerative diseases, cancer etc. [1,2]. Though wide-spectrum antibiotics are available they are least effective against infectious agents due to their increase in multi drug resistant nature. Products like carotenoids, vitamins and polyphenols from fruits and vegetables have the ability to modulate oxidative stress in human cells [3,4]. Yet, low bioavailability and easy degradation during delivery limit their antioxidant activity [5]. The change in the way the prescribed drugs used for the treatment of various diseases or the development of novel candidates with high potency is the urgent need of the hour.

Nanotechnology, an emerging research area in science and technology has gained importance in biomedical, cosmetics, imaging, cancer therapy and targeted drug delivery $[6,7]$. Nanostructures and nanodevices with controlled shape and size are designed and characterized for various applications by this innovative technique. Different types of metal nanoparticles like gold, silver, alginate, copper, titanium, zinc, magnesium, etc., are proved to have profound pharmacological activity [8]. Among the metallic nanoparticles, nanosilver is extensively researched for its wide-ranging applications in different fields. Sensors with silver-based nanocomposites and nanocatalysts have been developed for the removal of pollutants from environmental sample and health monitoring [9-11]. The good electrical conductivity and potential optical property of silver nanoparticles (AgNPs) attracted their role as catalysts in chemical reactions, as intercalating materials for electrical batteries, used in selective coatings for solar energy absorption, etc., [12, 13]. The broad-spectrum activity, low toxicity and unique physiological properties such as size, morphology and surface chemistry of $\operatorname{AgNPs}[14,15]$ acquired an interest in the development of antimicrobial [16], anti-plasmodial [17], anti-platelet [18], anti-tumour [19], topical creams and wound healing [20] pharmaceutical products. Factors like cell type and reducing agents from which the NPs are produced also influences the biological activity of AgNPs that extends the applications in constructions, plant science, veterinary, food, ecology, and electronics. Its potency to rupture thick cell wall, inducing oxidative stress, inhibiting proteins, enzymes and DNA replication circumvented the infections and multi drugresistant nature of microbial strains [21]. This antimicrobial property directed to the development of products like AgNPs integrated healing bandage, antiseptics and medical devices for sterilizing surfaces and air. AgNPs also proved to have significant cytotoxic activity in cancer cell lines and degenerative disease by reducing ROS [22, 23]. Its distinctive ability to cross various biological barriers, targeted delivery of drugs, increased synergistic effects of chemotherapeutic drugs with AgNPs, high biocompatibility with human cells lead to the design of Ag-based nanomaterials for medical applications [24].

Nanoparticles are synthesized by physicochemical methods that are costly, highly toxic and time-consuming. An eco-friendly, sustainable technique has to be developed for the production of AgNPs for various medical challenges. Biosynthesis of metal nanoparticles gained considerable attention in the past decade. Moreover, it has been proposed as a less toxic, cost-effective, environmentally friendly alternative to chemical and physical methods. Biological sources such as plants, microbes (bacteria and fungi) and biomolecules (amino acids and vitamins) are recognized to reduce metal ions to nano metals $[25,26]$. The biomoieties in the green extracts such as proteins, enzymes, vitamins, alcoholic compounds, alkaloids, flavonoids, phenols, quinones, terpenoids, tannins, saponins, sugars, sulfhydryls, pigments, amino acids, etc., influence the fabrication of nanoparticles that increases its microbial inhibitory and cellular toxicity nature, yet it is least toxic to human and environment [27].

Waltheria indica, a tropical medicinal plant is used traditionally in the treatment of cough, skin diseases, microbial infections and inflammatory diseases [28-30]. Endophytes have opened a new direction of exploration in nanoparticle synthesis. They colonize the internal tissues of plants, diversify between species, organs and play a key role in plant growth and defence. They are well known for the inimitable intracellular and extracellular bioactive metabolites that act as the major source of drugs against human diseases. Endophytic fungi from different plants are extensively studied for nanoparticle synthesis yet the potency of endophytic bacteria in nano research is at the primitive stage $[31,32]$. We explored the diversity of endophytic bacteria in the stem parts of $W$. indica and identified a novel bacterium Pantoea anthophila for the first time. The multidimensional property of endophytes may produce stable nanoparticles with high medicinal potency. This bottom-up approach may generate targeted nanomaterials at very high efficiency.

Nanoparticles biosynthesized extracellularly requires simple downstream processing and is cost-effective while intracellular synthesis involves additional purification steps to release the synthesized nanoparticles. The negligible use of toxic chemicals and sustainable large scale production of 
AgNPs is an added advantage to explore its potential applications. Hence current research widely focuses on the extracellular synthesis of AgNPs stabilised by bacterial metabolites that control their size, shape and dispersity [33, 34]. Based on these considerations, the present study has been designed to undertake the extracellular biosynthesis of silver nanoparticles (Pa-AgNPs) from $P$. anthophila and evaluate its therapeutic potential. To the best of our knowledge, this study is the first report on biofabrication, characterization, antimicrobial and antioxidant potentials of AgNPs biosynthesized from the bacterium $P$. anthophila isolated from W.indica plant. The study would also recommend the application of endophytic bacteria for nanoparticles synthesis in pharmaceutical applications as an alternative greener approach.

\section{Materials and Methods}

\subsection{Chemicals, Endophytic Bacteria, and Microbial Strains}

Analytical grade silver nitrate $\left(\mathrm{AgNO}_{3}, 99 \%\right.$ pure $)$, tetracycline, kanamycin, nutrient agar, potato dextrose agar, Mueller-Hinton agar used in the present study are purchased from Himedia Lab, Ltd., Mumbai, India. The endophytic bacteria Pantoea anthophila (GenBank accession no. MN077163) identified earlier by $16 \mathrm{~S}$ ribosomal RNA gene sequencing from $W$. indica were pure cultured and stored in the Department of Biotechnology, Vinayaka Mission's Kirupananda Variyar Engineering College, Salem. Bacterial pathogens such as Gram-positive Staphylococcus epidermidis (MTCC737), Bacillus subtilis (MTCC1133), Staphylococcus aureus (MTCC2940), Gram-negative Escherichia coli (MTCC40), Proteus mirabilis (MTCC425), Salmonella typhi (MTCC733), Klebsiella pneumoniae (MTCC2405) and fungal strains of Aspergillus niger (MTCC404), Candida albicans (MTCC183) and Penicillium chrysogenum (MTCC947) were obtained from Microbial Type Culture Collection (MTCC), Chandigarh.

\subsection{Preparation of Cell-Free Endophytic Culture}

Pantoea anthophila $(\mathrm{Pa})$ isolated from $W$. indica are subcultured and maintained in nutrient agar plates. A loopful of Pa culture is inoculated in $100 \mathrm{ml}$ of Luria-Bertani broth at $37{ }^{\circ} \mathrm{C}$ and placed in an orbital shaker at $200 \mathrm{rpm}$ overnight. When the optical density (OD) of the culture was 0.242 at $600 \mathrm{~nm}$, it was taken in $50 \mathrm{ml}$ falcon vials and centrifuged at $10,000 \mathrm{rpm}$ for $10 \mathrm{~min}$ in a high-speed centrifuge (RM-03 Plus). The extracellular broth devoid of cells were collected in a sterile beaker and used for AgNP synthesis.

\subsection{Biosynthesis of Pa-AgNPs}

The $10 \mathrm{ml}$ of bacterial cell-free suspension was mixed with $90 \mathrm{ml}$ of $1 \mathrm{mM}(2 \%, \mathrm{v} / \mathrm{v}) \mathrm{AgNO}_{3}$ solution in deionized water for the biosynthesis of AgNPs at neutral $\mathrm{pH}$. The reaction mixture was incubated at $30{ }^{\circ} \mathrm{C}$ for $24 \mathrm{~h}$ in dark to avoid any photochemical reactions [35, 36]. Simultaneously, the cellfree supernatant without $\mathrm{AgNO}_{3}$ was maintained as control. The formation of Pa-AgNPs was monitored by the colour change in the bacterial extract and separated by centrifuging at 10,000 rpm for $15 \mathrm{~min}$. The water-soluble biological molecules and other impurities are removed by washing the samples repeatedly $(\times 3)$ with deionized water. The final mass of the AgNPs was collected and freeze-dried.

\subsection{Biophysical Characterization of Pa-AgNPs}

The Pa-AgNPs are further characterized by UV-Visible spectroscopy, Dynamic Light scattering analysis (DLS), Zeta potential, Fourier Transform Infrared Spectroscopy (FTIR), X-ray Diffraction (XRD), Transmission Electron Microscopy (TEM), Scanning Electron Microscopy (SEM), Energy Dispersive of X-Ray spectrum (EDAX).

The formation of AgNPs was confirmed by measuring the absorption spectra in UV-Visible spectroscopy (SHIMADZU 1800). The reaction mixture was scanned at the speed of $300 \mathrm{~nm} \mathrm{~min}^{-1}$ in 200-600 $\mathrm{nm}$ range. DLS analysis determines the particle size and distribution pattern of $\mathrm{Pa}$ AgNP. Zeta sizer (Malvern Instruments Ltd., U.K ZS90) was used to determine the surface charge potential, the magnitude of charge attraction or repulsion and electrophoretic stability of Pa-AgNP.

The FTIR analysis was carried out to identify the functional biomolecules in the endophytic extract that reduces $\mathrm{Ag}^{+}$to AgNPs and the capping agents that stabilize the nanoparticles. The Pa-AgNPs is scanned at the transmission mode ranging from 500 to $4000 \mathrm{~cm}^{-1}$ in a solid phase, at a resolution of $1 \mathrm{~cm}^{-1}$ using FTIR spectrophotometer (SHIMADZU, IR PRESTIGE 21). XRD pattern provides the details of the structure and composition of Pa-AgNPs. The sample was analyzed by Shimadzu XRD 6000 diffractometer operated at $40 \mathrm{kV}$ voltage, $30 \mathrm{~mA}$ current in a scanning mode range of $\theta-2 \theta$ between $10^{\circ}$ and $80^{\circ}$ with sampling pitch of $0.1000^{\circ}$ equipped with a $\mathrm{Cu} \mathrm{K} \alpha$ radiation.

The crystallite structure of the Pa-AgNP was measured using TEM (JEOL JEM 2100). The sample was placed on copper grids coated carbon films, dried at room temperature and analysed at $200 \mathrm{kV}$. SEM shows the size, shape and surface morphological properties of $\mathrm{Pa}-\mathrm{AgNP}$ synthesized from the endophytic extract. The nanoparticle was observed in SEM (JEOL-JSM 6390) at a voltage of 15-20 kV at different magnifications. The atomic composition of $\mathrm{Pa}-\mathrm{AgNP}$ 
was confirmed by EDAX analysis (Oxford instrument, INCA PentaFET $\times 3$ ) coupled with SEM.

\subsection{Antimicrobial Screening of Pa-AgNPs}

The antimicrobial activity of the synthesized Pa-AgNPs was analysed by Agar well diffusion method [37] in triplicates. The bacterial strains $S$. epidermidis, B. subtilis, $S$. aureus, E. coli, P. mirabilis, S. typhi, K. pneumonia were inoculated in nutrient media and incubated at $37{ }^{\circ} \mathrm{C}$ for $2-4 \mathrm{~h}$. At the exponential growth phase, the organisms are cultured in Muller Hinton agar plates in which six wells of about $5 \mathrm{~mm}$ diameter were bored. Different concentrations of Pa-AgNPs ( $25 \mu \mathrm{g} / \mathrm{ml}, 50 \mu \mathrm{g} / \mathrm{ml}, 75 \mu \mathrm{g} / \mathrm{ml}, 100 \mu \mathrm{g} / \mathrm{ml}), 10 \mu \mathrm{g} / \mathrm{ml}$ of dimethyl sulfoxide (DMSO) (negative control) and Tetracycline (positive control) were added to the wells.

Similarly, the fungal strains A. niger, C. albicans and $P$. chrysogenum were inoculated in potato dextrose agar in which the antifungal activity of Pa-AgNPs at different concentrations $(25 \mu \mathrm{g} / \mathrm{ml}, 50 \mu \mathrm{g} / \mathrm{ml}, 75 \mu \mathrm{g} / \mathrm{ml}, 100 \mu \mathrm{g} / \mathrm{ml})$ are evaluated with Kanamycin $(10 \mu \mathrm{g} / \mathrm{ml})$ as a positive control. The plates were incubated for $24 \mathrm{~h}$ at $37{ }^{\circ} \mathrm{C}$ to observe the clear zones of inhibition (ZOI). The diameter of clear zones was measured and recorded.

\subsection{Antioxidant Efficacy of Pa-AgNPs}

\subsubsection{1, 1-Diphenyl-2-picrylhydrazyl (DPPH) Radical Scavenging Assay}

DPPH radical scavenging assay potential of Pa-AgNPs was assayed [38] at different concentrations $(10,20,30,40 \&$ $50 \mu \mathrm{g} / \mathrm{ml}$ ) of Pa-AgNPs and standard ascorbic acid. In methanol solution, dissolved $50 \mu \mathrm{l}$ of $0.659 \mathrm{mM}$ DPPH added to the samples and the volume is made up to one with double distilled water. The tubes were incubated in dark at $25^{\circ} \mathrm{C}$ for $20 \mathrm{~min}$ and the absorbance was recorded at $510 \mathrm{~nm}$ using Shimadzu UV 1800 spectrophotometer. The \% inhibition (I\%) was calculated as $(\mathrm{I} \%)=100 \times\left(\mathrm{A}_{0}-\mathrm{A}_{1}\right) / \mathrm{A} 0$, Where $\mathrm{A}_{0}$ is the absorbance of the control, $A_{1}$ is the absorbance of the Pa-AgNPs and standard.

\subsubsection{Nitric Oxide Radical Scavenging Assay}

At physiological $\mathrm{pH}$, in an aqueous solution, sodium nitroprusside generates nitric oxide that interacts with oxygen to produce nitrite ions, which can be measured in the presence of Griess reagent [38]. To various concentrations (10-50 $\mu \mathrm{g} /$ $\mathrm{ml}$ ) of Pa-AgNPs and standard ascorbic acid, added $50 \mu \mathrm{l}$ of $10 \mathrm{mM}$ sodium nitroprusside dissolved in $0.5 \mathrm{M}$ phosphate buffer ( $\mathrm{pH}$ 7.4) and incubated under fluorescent light at room temperature for $15 \mathrm{~min}$. Added $125 \mu \mathrm{l}$ of Griess reagent, the tubes were incubated again at room temperature for $10 \mathrm{~min}$ and the absorbance was recorded at $546 \mathrm{~nm}$.

\subsubsection{Hydrogen Peroxide $\left(\mathrm{H}_{2} \mathrm{O}_{2}\right)$ Scavenging Assay}

The ability of the Pa-AgNPs to scavenge $\mathrm{H}_{2} \mathrm{O}_{2}$ was determined according to the method of Nabavi et al. [39]. $0.6 \mathrm{ml}$ of $40 \mathrm{mM}$ of $\mathrm{H}_{2} \mathrm{O}_{2}$ was prepared using $50 \mathrm{mM}$ phosphate buffer ( $\mathrm{pH} 7.4$ ) and added to varied concentrations $(10-50 \mu \mathrm{g} / \mathrm{ml})$ of Pa-AgNPs and standard ascorbic acid. The tubes were incubated for $10 \mathrm{~min}$ and the absorbance was noted at $230 \mathrm{~nm}$.

\subsubsection{Total Antioxidant Capacity Assay}

The total antioxidant capacity assay was determined [40] by adding $1 \mathrm{ml}$ of reagent solution containing sulphuric acid $(0.6 \mathrm{M})$, sodium phosphate $(28 \mathrm{mM})$ and ammonium molybdate $(4 \mathrm{mM})$ to Pa-AgNPs and standard ascorbic acid $(10-50 \mu \mathrm{g} / \mathrm{ml})$. The tubes were capped, incubated at $95{ }^{\circ} \mathrm{C}$ for $90 \mathrm{~min}$ in a thermal block and then cooled to room temperature, the absorbance was measured at $695 \mathrm{~nm}$.

\subsubsection{2,2'-Azino-bis-3-Ethyl Benzothiozoline-6-Sulfonic Acid (ABTS) Radical Scavenging Activity}

The assay is based on the scavenging of light by ABTS radicals. An antioxidant that donates a hydrogen atom will quench the stable free radical which can be quantified spectrometrically at $734 \mathrm{~nm}$ [38]. $200 \mu \mathrm{l}$ of $70 \mathrm{mM}$ potassium persulphate and $50 \mathrm{ml}$ of $2 \mathrm{mM} \mathrm{ABTS}$ were mixed before 2hours. To the $0.5 \mathrm{ml}$ of various concentrations $(10-50 \mu \mathrm{g} /$ $\mathrm{ml}$ ) of Pa-AgNPs and standard ascorbic acid, $0.3 \mathrm{ml}$ of ABTS radical cation and $1.7 \mathrm{ml}$ of phosphate buffer $(\mathrm{pH}$ 7.4) was added and the absorbance was measured.

\subsubsection{Reducing Power Assay}

Different concentrations (10-50 $\mu \mathrm{g} / \mathrm{ml})$ of Pa-AgNPs solution were mixed with $2.5 \mathrm{ml}$ of $200 \mathrm{mM}$ phosphate buffer (pH 6.6) and $1 \%$ potassium ferricyanide each. Incubated at $50{ }^{\circ} \mathrm{C}$ for $20 \mathrm{~min}$, the mixture was cooled rapidly. Subsequently, added $2.5 \mathrm{ml}$ of $10 \%$ Trichloroacetic acid and centrifuged at $3000 \mathrm{rpm}$ for $10 \mathrm{~min}$. The supernatant $(5 \mathrm{ml})$ with an equal amount of distilled water were mixed and added to $1 \mathrm{ml}$ of $0.1 \%$ ferric chloride. Using ascorbic acid as a standard, the absorbance was measured at $700 \mathrm{~nm}$ [41].

\subsubsection{Superoxide $\left(\mathrm{O}_{2}^{-}\right)$Radical Scavenging Assay}

The superoxide scavenging activity of the Pa-AgNPs was assayed by the reduction of nitro blue tetrazolium (NBT) [42]. To Pa-AgNPs solution (10-50 $\mu \mathrm{g} / \mathrm{ml}), 3 \mathrm{ml}$ Tris- $\mathrm{HCl}$ 
buffer $(16 \mathrm{mM}, \mathrm{pH} 8), 1 \mathrm{ml}$ NBT $(50 \mu \mathrm{M}), 1 \mathrm{ml}$ Nicotinamide Adenine Dinucleotide $(78 \mu \mathrm{M})$ and $1 \mathrm{ml}$ phenazine methosulfate (PMS) solution $(10 \mu \mathrm{M})$ were mixed and kept for $5 \mathrm{~min}$ at $25^{\circ} \mathrm{C}$. The absorbance was recorded at $560 \mathrm{~nm}$. Ascorbic acid was used as standard.

Inhibition \% versus concentration curve was plotted for each assay and the concentration of sample required for $50 \%$ inhibition was determined and expressed as $\mathrm{IC}_{50}$ value. The lower $\mathrm{IC}_{50}$ value indicates a high antioxidant capacity.

\section{Results and Discussion}

\subsection{Biosynthesis and Characterization Studies of Pa-AgNPs}

\subsubsection{UV-Visible Spectroscopy}

The yellow colour of bacterial extract, when mixed with $\mathrm{AgNO}_{3}$ turned dark brown after $24 \mathrm{~h}$ (Fig. 1b), at the same time, no colour change was detected in the control (Fig. 1a). This colour change is due to the reduction of $\mathrm{Ag}^{+}$to $\mathrm{Ag}^{0}$ in the aqueous solution that occurs due to excitation of surface plasmon resonance (SPR) in AgNPs [43]. The free electrons of Ag metal oscillate in resonance with reflected light and induce this phenomenon. Also, the shape, size and the interaction of bacterial metabolites with AgNPs influences this property that can be measured by spectroscopic methods. Usually, the SPR peak of AgNPs lies in the range of 400-500 nm. Pa-AgNPs exhibited a maximum absorption at the wavelength $410 \mathrm{~nm}$ that confirms the characteristics of AgNPs (Fig. 2). Khatoon et al. [44] reported similar UV absorption spectra for chemically synthesized AgNPs that had promising antifungal activity. Similar peaks were also reported in many studies $[35,45]$ relevant to the biosynthesis of AgNPs.

\subsubsection{DLS and Zeta Potential Analysis}

The bioefficiency of the AgNPs depends on the size and surface charge that prevents agglomeration. The DLS analysis (Fig. 3) showed that the average size of Pa-AgNPs was $16 \mathrm{~nm}$ and the size varies from 10 to $24 \mathrm{~nm}$. The zeta potential of the Pa-AgNPs was found as a sharp peak at $5.30 \mathrm{mV}$ (Fig. 4) which indicates that the surface of synthesized nanoparticles was positively charged. This positive charge may be due to the capping of bioactive metabolites on the surface. Ali et al. [46] showed zeta potential value of AgNPs synthesized from apple extract was $5.68 \pm 3.28 \mathrm{mV}$ that had strong agglomeration and precipitation. Prakasham et al. [47] also
Fig. 1 a Endophytic bacterial extract (Control). b Endophytic bacterial extract mixed with $\mathrm{AgNO}_{3}$ after $24 \mathrm{~h}$

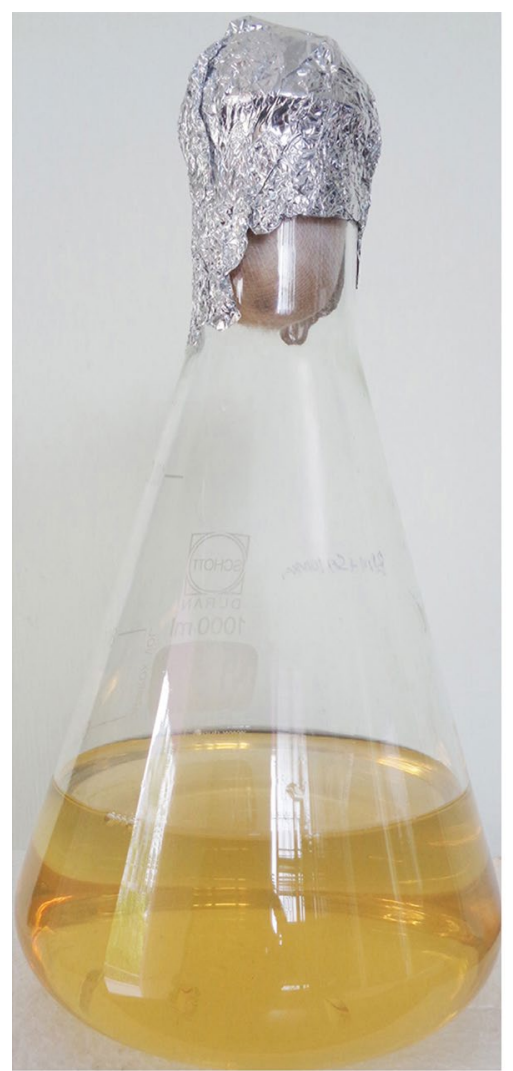

(a)

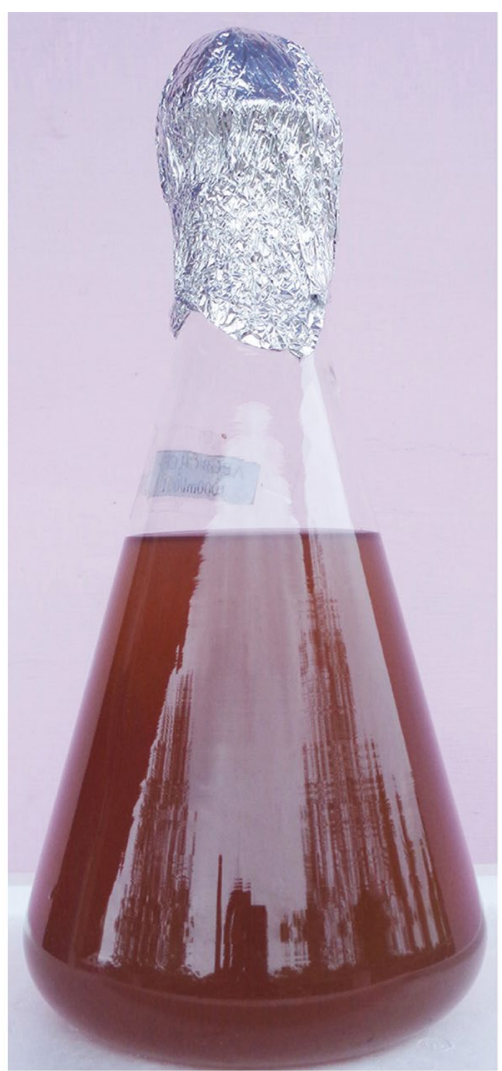

(b) 


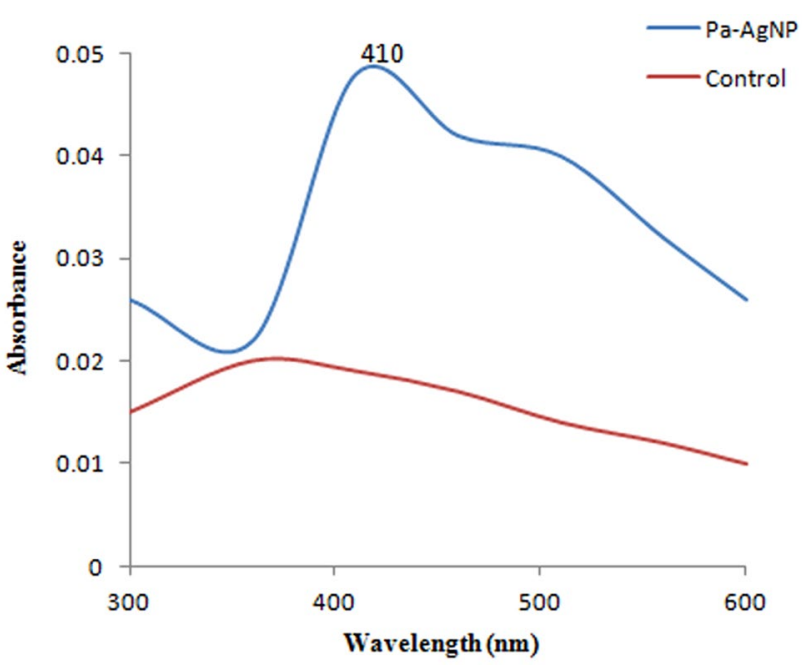

Fig. 2 UV-visible absorption spectrum of Pa-AgNPs

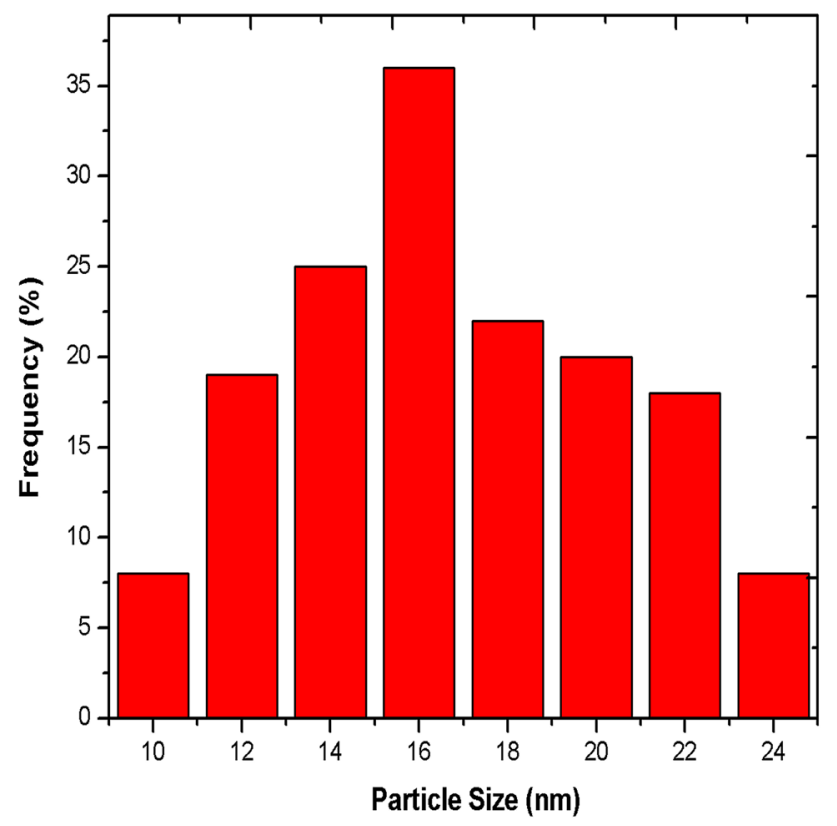

Fig. 3 Size distribution of Pa-AgNPs by Dynamic Light scattering analysis technique

synthesized AgNPs from marine Streptomyces albidoflavus that had $-8.5 \mathrm{mV}$ zeta potential with strong antimicrobial activity. In agreement with the above reports, Pa-AgNPs had the same zeta potential for more than 100 days that proved their stability with strong antimicrobial and antioxidant activities.

\subsubsection{FTIR Spectroscopy Study}

FTIR spectrum displayed the presence of predominant bands at $3423.65,1633.71,1022.27,607.58 \mathrm{~cm}^{-1}$ (Fig. 5). The peak at $3423.65 \mathrm{~cm}^{-1}$ corresponds to the $\mathrm{O}-\mathrm{H}$ stretching vibrations of water molecules. The bands at $1633.71 \mathrm{~cm}^{-1}$ show $\mathrm{C}=\mathrm{C}$ stretching vibrations of the non-conjugated, disubstituted alkene group. The band at $1022.27 \mathrm{~cm}^{-1}$ can be assigned to medium $\mathrm{C}-\mathrm{N}$ stretching vibrations of amines signifying the presence of amino acid. The peak obtained at $607.58 \mathrm{~cm}^{-1}$ regions could be attributed to alkyl halides stretching. The results obtained coincide with the earlier findings of similar AgNPs FTIR prediction [36, 48] that revealed the presence of hydroxyl, alkene and amine groups in the bacterial extract acting as reducing, capping and stabilizing agents of silver ions.

\subsubsection{XRD Analysis}

XRD analysis showed the strongest Braggs peaks at $2 \theta$ values of $38.30^{\circ}, 44.62^{\circ}, 65.01^{\circ}$ and $77.27^{\circ}$ (Fig. 6). These peaks are conferred to $100,200,220$ and 311 planes of a face centred cubic structure (FCC) of Pa-AgNPs that agrees with the JCPDS file no. 87-0720 for silver [49]. The crystallite domain sizes of Pa-AgNPs were calculated using Debye-Scherrer formula [50] $\mathrm{D}=0.94 \lambda / \beta \cos \theta$, where $\mathrm{D}$ is the average crystallite domain size perpendicular to the reflecting planes, $\lambda$ is the X-ray wavelength, $\beta$ is the full width at half maximum (FWHM), and $\theta$ is the diffraction angle. The average crystallite size was found to be $16.8 \mathrm{~nm}$ which was in close agreement with DLS analysis. No secondary peaks were observed, hence the crystalline stable AgNP formation from the endophytic extract is justified with the previous XRD data green synthesized from endophytic bacteria, fungi and plant extracts $[36,51,52]$.

\subsubsection{TEM Measurement}

The antimicrobial activity of AgNPs is greatly influenced by their shape and size [53]. The TEM micrographs (Fig. 7) exposed that $\mathrm{Pa}-\mathrm{AgNPs}$ have a spherical shape with an average size of $20 \pm 1.1 \mathrm{~nm}$. They were found to be circular aggregates with smooth edges that are not in direct contact with each other, which indicates the Pa-AgNPs may be stabilized by capping agents from the endophytic extract. Figure 8 shows the selected area electron diffraction (SAED) pattern of Pa-AgNPs with 100, 200, 220 and 311 crystal alignments matching with diffraction rings that were in agreement with XRD data. The presence of bright spots within the diffraction rings of crystal orientations confirms the FCC structure $\mathrm{Pa}-\mathrm{AgNP}$ with polycrystalline nature. The average size of the particle was also nearly in congruence with DLS analysis. The results obtained were identical to earlier reports of green synthesized AgNPs [31, 54]. The small size of nanoparticles may enhance the reactivity and catalytic activity in various applications. 
Fig. 4 Graphical presentation of Zeta potential of Pa-AgNPs
Zeta Potential Distribution

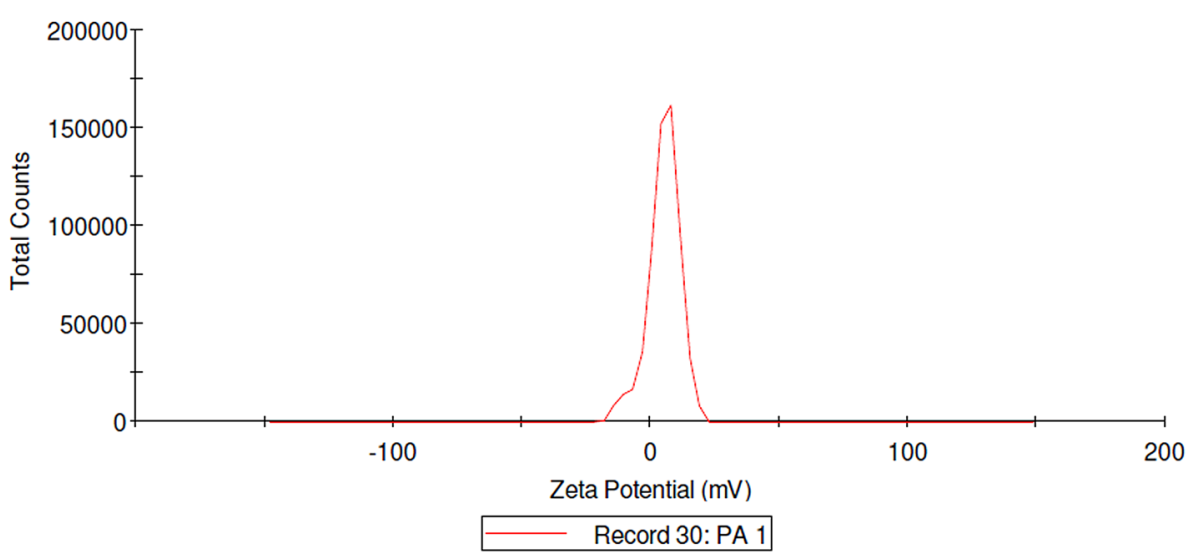

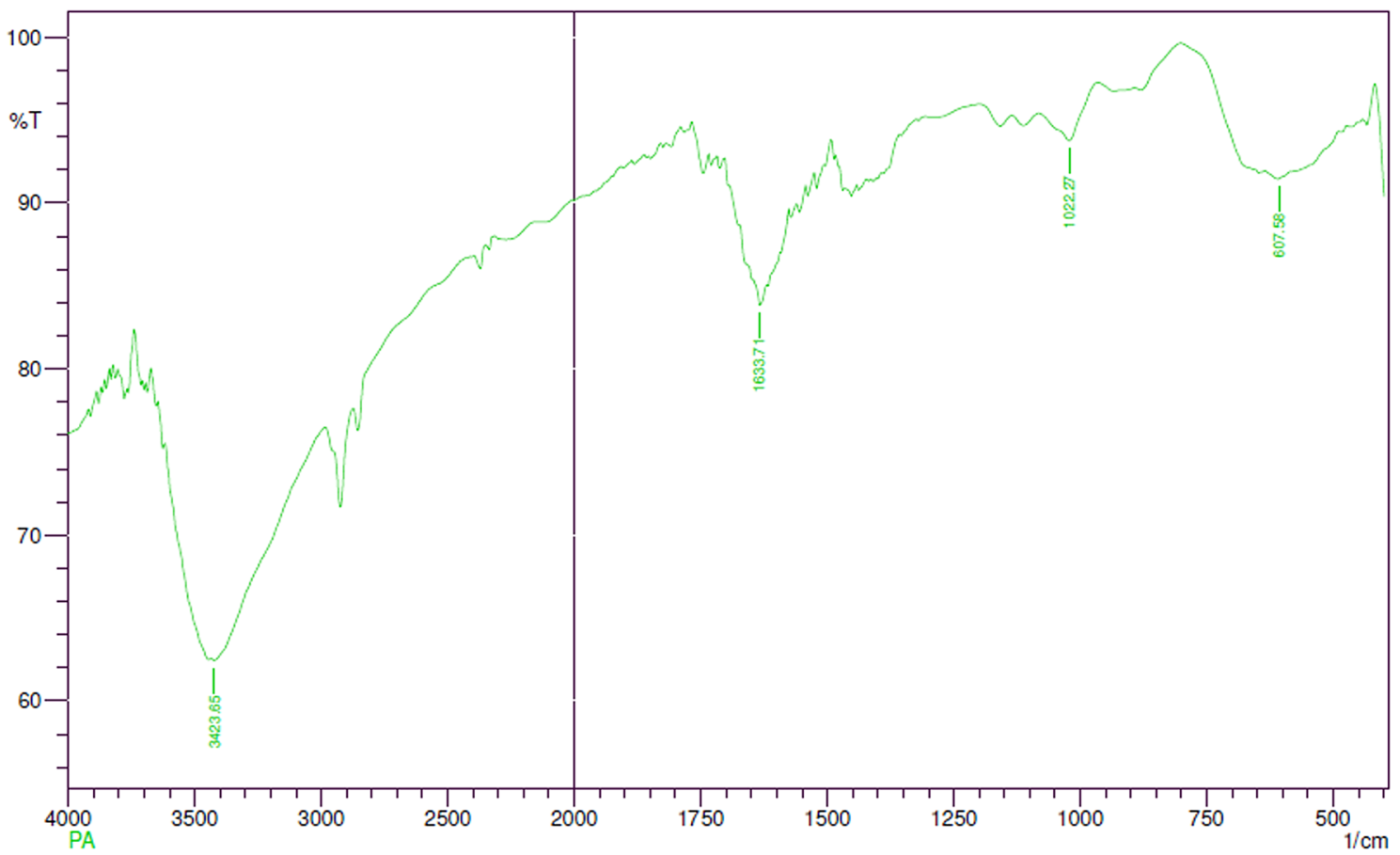

Fig. 5 Fourier Transform Infrared spectrum of Pa-AgNPs

\subsubsection{SEM and EDAX}

The SEM micrograph (Fig. 9) showed that the Pa-AgNPs were spherical shaped, nonuniform polydispersed with an average size of $50 \mathrm{~nm}$. The smaller particles may aggregate to give the large-size appearance of nanoparticles [54]. The large particle size depicted in SEM compared to DLS, XRD and TEM may be due to the difference in sample preparation and the presence of various forces of interaction in the solution [55, 56]. The elemental analysis of Pa-AgNPs done using EDAX (Fig. 10) showed a sharp absorption peak between $3-4 \mathrm{keV}$ that is typical of the presence of metallic
AgNPs. The additional peak for Fe were also observed that may be due to the trapping of proteins and other metabolites from the bacterial extract on AgNPs [35, 55]. The weight of silver was found to be $41.77 \%$, thus confirms Pa-AgNPs was successfully biosynthesized from endophytic bacterial extracts.

\subsection{Antimicrobial Screening of Pa-AgNPs}

Pa-AgNPs showed promising antimicrobial activity in a dose-dependent manner. Significant antibacterial activity with minimum ZOI of $4.83 \pm 0.21 \mathrm{~mm}$ against $S$. aureus, 


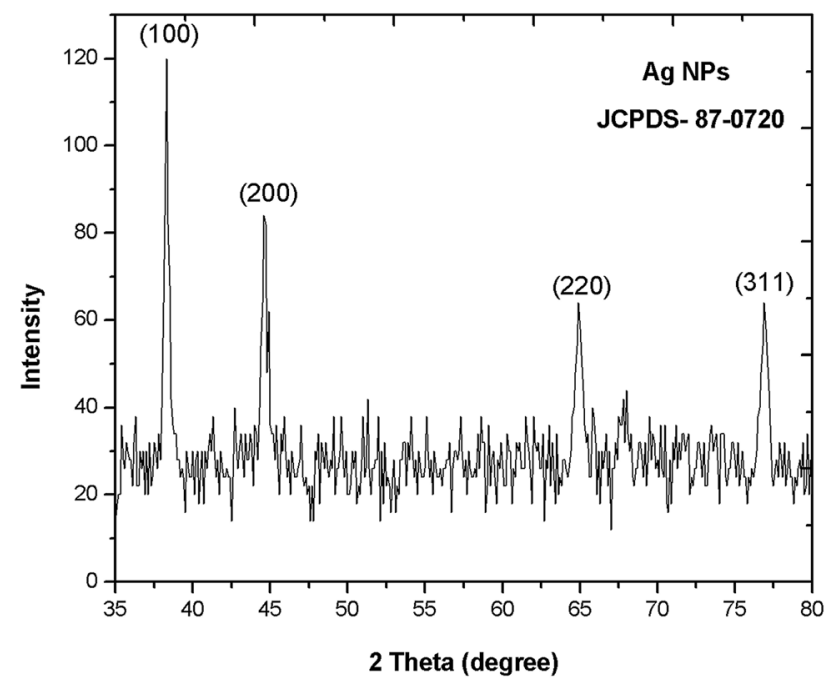

Fig. 6 X-ray Diffraction analysis of crystal structure of Pa-AgNPs

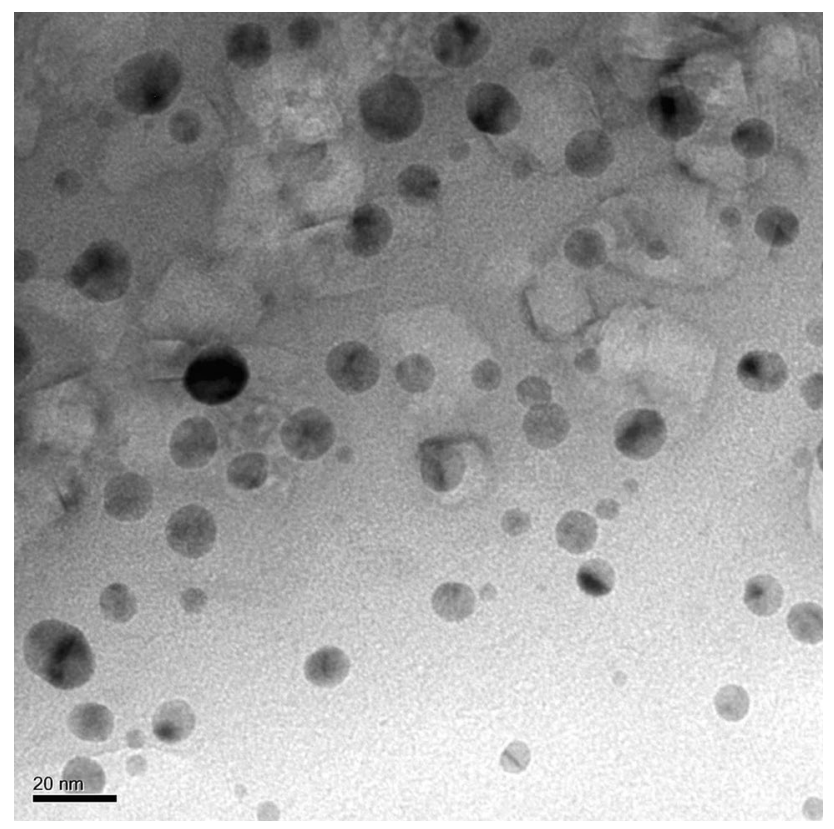

Fig. 7 Transmission Electron Microscopy pattern of Pa-AgNPs

$4.93 \pm 0.21 \mathrm{~mm}$ against $S$. epidermidis, $P$. mirabilis, and $4.03 \pm 0.06,4.03 \pm 0.21,4.03 \pm 0.15 \mathrm{~mm}$ against $E$. coli, $S$. typhi and $K$. pneumonia at $25 \mu \mathrm{g} / \mathrm{ml}$ was observed. The maximum ZOI between $6.83 \pm 0.29$ to $7.03 \pm 0.06 \mathrm{~mm}$ was observed at $100 \mu \mathrm{g} / \mathrm{ml}$ for all pathogens, Comparatively $B$. Subtilis exhibited low activity of $5 \pm 0.10 \mathrm{~mm}$ at $100 \mu \mathrm{g} / \mathrm{ml}$ (Fig. 11). The diameters of the ZOI developed by Pa-AgNPs compared to the tetracycline standard for the bacterial pathogens (Table 1) are illustrated in Fig. 12. Hu et al. [57] observed similar ZOI by AgNPs synthesized from endophytic fungi Talaromyces purpureogenus against $S$. aureus,

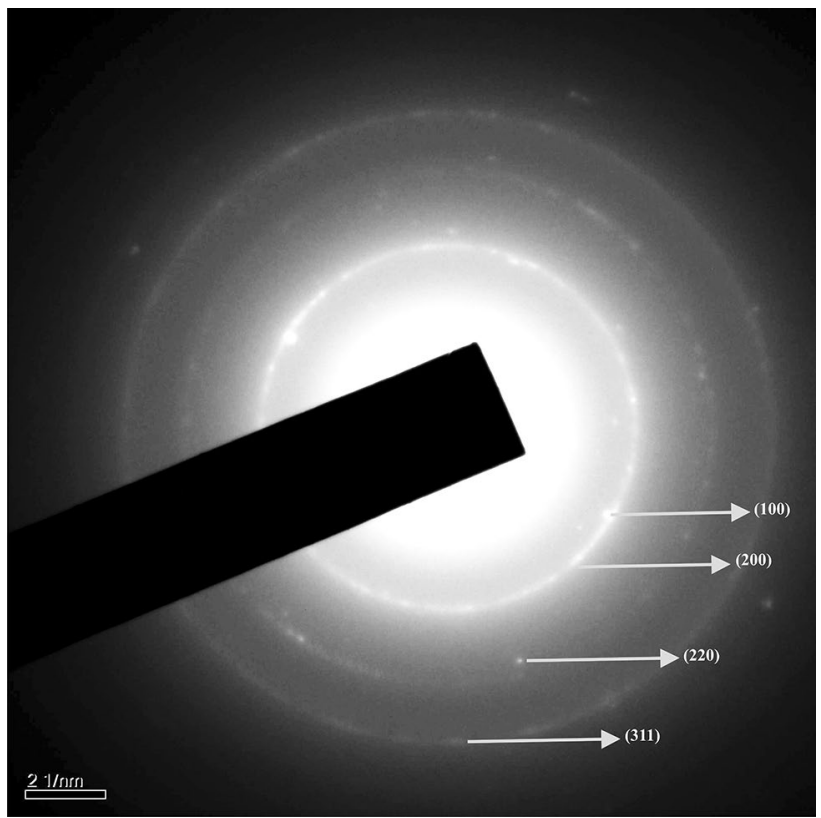

Fig. 8 Selected area electron diffraction pattern of Pa-AgNPs

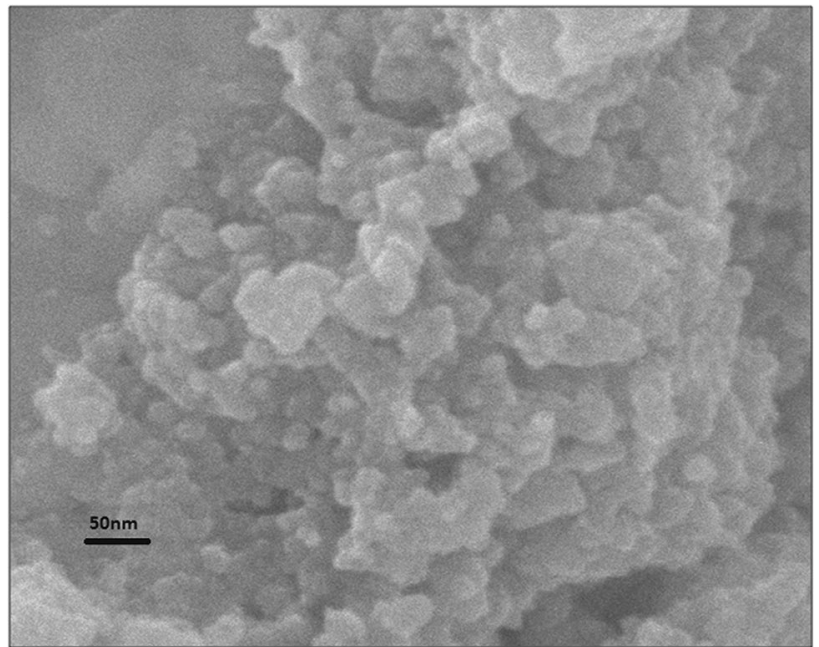

Fig. 9 Scanning Electron Microscopy image of Pa-AgNPs

B. cereus, S. enterica, P. aeruginosa and E. coli. Khatoon et al. [58] chemically synthesized AgNPs using tri-sodium citrate that had higher antibacterial activity against $E$. coli, followed by $B$. subtilis which was similar to our results. The results obtained confirm the broad-spectrum activity of Pa-AgNPs against both Gram-positive and Gram-negative bacteria.

Penicillium chrysogenum and Candida albicans had $\mathrm{ZOI}$ of $4.10 \pm 0.10 \mathrm{~mm}(100 \mu \mathrm{g} / \mathrm{ml})$ and $7.10 \pm 0.10 \mathrm{~mm}$ to $11.03 \pm 0.15 \mathrm{~mm}$ (dose-dependent) (Fig. 13) respectively, whereas there is no ZOI for A. Niger (Table 2). Hence, the 


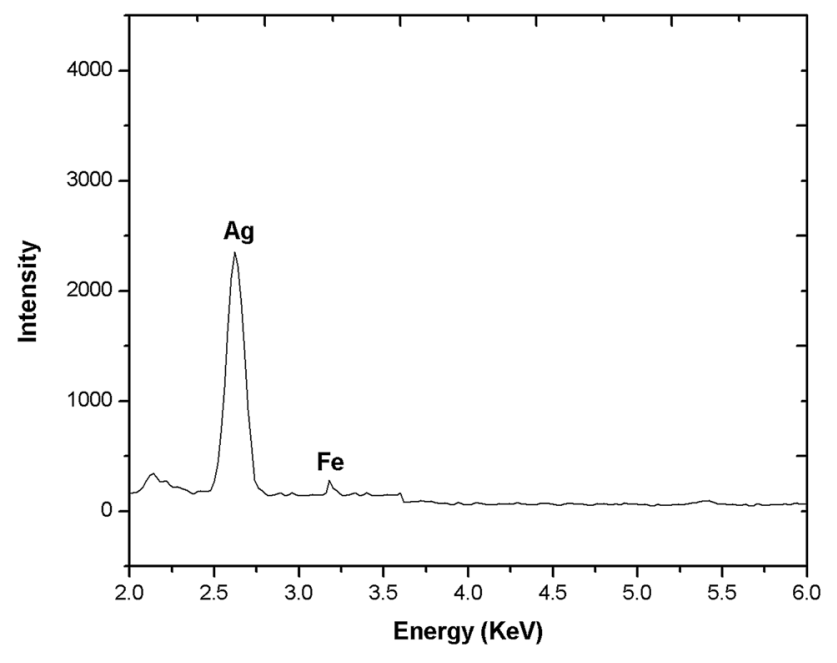

Fig. 10 Elemental composition of Pa-AgNPs using EDAX profile

growth of C. albicans was greatly controlled than Penicillium and Aspergillus. The antimicrobial effect of Pa-AgNPs biosynthesized from endophytic bacteria isolated from $W$. indica against $C$. albicans was strong when compared to the crude W. indica leaf extracts reported by Koma et al. [28].

Though different rational mechanisms elucidate the antimicrobial activity of AgNPs, the interpretations are uncertain and researchers are still working to identify the exact mechanism. Khatoon et al. [43] were able to obtain the highest antifungal activity with AgNPs of $24 \mathrm{~nm}$ size against $S$. cerevisiae and C.albicans than AuNPs of $35 \mathrm{~nm}$. Hence the small particle size of about $16.8 \mathrm{~nm}$ may attribute to the antimicrobial activity of Pa-AgNPs. At higher concentration, the $\mathrm{Pa}-\mathrm{AgNPs}$ were able to break the thick peptidoglycan layer of Gram-positive as well as thin layered Gram-negative bacterial cell wall strongly than at the lower concentrations. The much thicker cell wall of fungal species compared to bacteria make a difference in the antifungal activity of Pa-AgNPs [58]. Hence the concentration of the AgNPs and microbial species type influence the antimicrobial activity. According to Levard et al. [59] the positive surface charge of Pa-AgNPs may contribute to the inhibitory effects of bacterial species. $\mathrm{Ag}^{+}$ions released from Pa-AgNPs binds with the cell wall, alters the membrane potential and transmembrane electrochemical gradient. The AgNPs also binds with the DNAthat leads to DNAdamage and ROS generation ultimately causes cell death. Hence our results justify the plausible mechanisms (Fig. 14) for potent microbicidal activity of Pa-AgNPs that were in accordance with the reported literature [60-62] of AgNPs synthesized by biogeneic approach.

To the best of our knowledge, the present study is the first scientific report on the potential of Pa-AgNPs against human pathogenic microbes. The study can be extended against MDR bacteria, other clinical pathogens and pandemic viruses to overcome the current challenging situations. The low cost biosynthesized AgNPs can also be used to reduce the secondary risks caused in COVID-19 patients.

\subsection{Antioxidant Efficacy of Pa-AgNPs}

The DPPH radical, $\mathrm{H}_{2} \mathrm{O}_{2}$ radical and ABTS radical scavenging activity of Pa-AgNPs increased in a dose-dependent manner from $36.99 \pm 0.61 \%$ to $61.31 \pm 0.47 \%, 28.36 \pm 0.90$ to $56.37 \pm 0.91 \%$ and $31.94 \pm 1.84 \%$ to $67.44 \pm 1.39 \%$ respectively at the concentration from 10 to $50 \mu \mathrm{g} / \mathrm{ml}$, which is comparable with standard ascorbic acid that had $20.97 \pm 0.89 \%$ to $64.64 \pm 1.06 \%, 29.95 \pm 1.27$ to $66.96 \pm 1.85 \%, 33.11 \pm 1.40$ to $70.47 \pm 1.49 \%$ of inhibition respectively (Fig. 15a, b, c).

The reducing power of compounds also increased analogous to their antioxidant ability. The reductive capability of the Pa-AgNPs increased from $37.71 \pm 1.51$ to $64.51 \pm 0.94 \%$, while it is $37.81 \pm 1.45 \%$ to $58.39 \pm 1.12 \%$ at the same concentration for standard (Fig. 15d).

Pa-AgNPs scavenges the superoxide and nitric oxide radical up to $62.57 \pm 0.87 \%$ and $68.59 \pm 1.21 \%$ at $50 \mu \mathrm{g} / \mathrm{ml}$ that was comparable to the scavenging effect of ascorbic acid $55.54 \pm 1.23 \%$ and $70.54 \pm 0.96 \%$ at $50 \mu \mathrm{g} / \mathrm{ml}$ (Fig. 15e, f). The total antioxidant capacity of the Pa-AgNPs showed the highest inhibition of $62.22 \pm 1.75 \%$ at $50 \mu \mathrm{g} / \mathrm{ml}$, while the reference showed $69.41 \pm 1.16 \%$ at the same concentration (Fig. 15g).

Thus Pa-AgNPs have strong DPPH radical scavenging activity, nitric oxide radical scavenging activity and reducing power activity when compared to the standard. The $\mathrm{H}_{2} \mathrm{O}_{2}$ radical scavenging assay, total antioxidant capacity assay and ABTS radical scavenging assay, standard ascorbic acid showed strong antioxidant activity than Pa-AgNPs. The superoxide radical scavenging activity was similar for both Pa-AgNPs and standard. Netala et al. [63] observed $55.62 \pm 0.25 \%$ of inhibition in DPPH radical scavenging assay at $50 \mu \mathrm{g} / \mathrm{ml}$ by AgNPs synthesized by endophytic fungi that were lower than that obtained by Pa-AgNPs. Also, the nitric oxide radical, $\mathrm{H}_{2} \mathrm{O}_{2}$ radical scavenging and reducing assay of biogenic AgNPs reported at $50 \mu \mathrm{g} / \mathrm{ml}$ was lower than that obtained by Pa-AgNPs [64]. The results were also in line with the previous reports $[65,66]$. The comparison of $\mathrm{IC}_{50}$ in each assay is illustrated in Table 3 and the lower $\mathrm{IC}_{50}$ values show the higher antioxidant potency of the Pa-AgNPs.

Thus Pa-AgNPs was proved to have strong antioxidant activity that may occur due to the adsorption of functional groups from the endophytic extract on the surface of $\mathrm{Pa}$ AgNPs [67]. The excellent radical scavenging activity of $\mathrm{Pa}-\mathrm{AgNPs}$ admit them to be used as potent antioxidants or as a valuable component of antioxidant formulations in biomedical and pharmaceutical fields [68]. The antioxidant 
Fig. 11 Antibacterial activity of Pa-AgNPs against a $B$. subtilis, b $S$. aureus, c $S$. epidermidis, d $E$. coli, e $K$. pneumonia, f $P$. mirabilis, g S. typhi

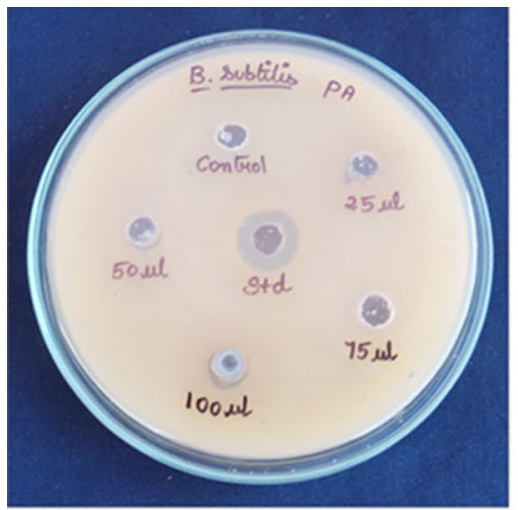

(a)

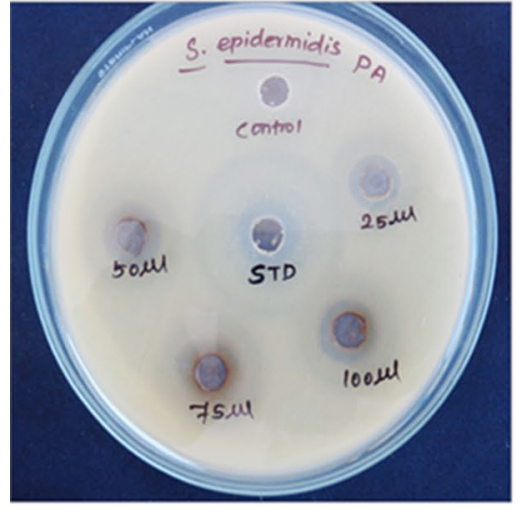

(c)

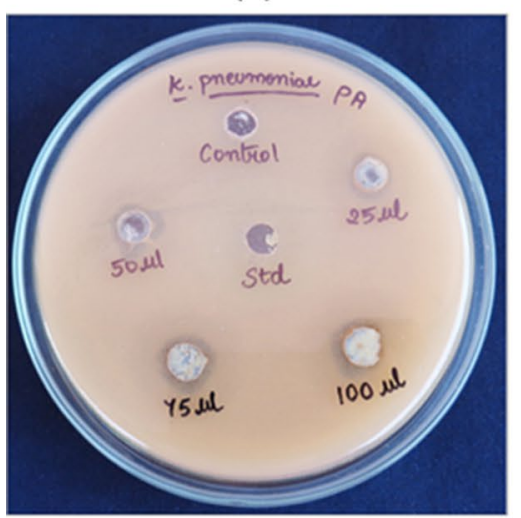

(e)

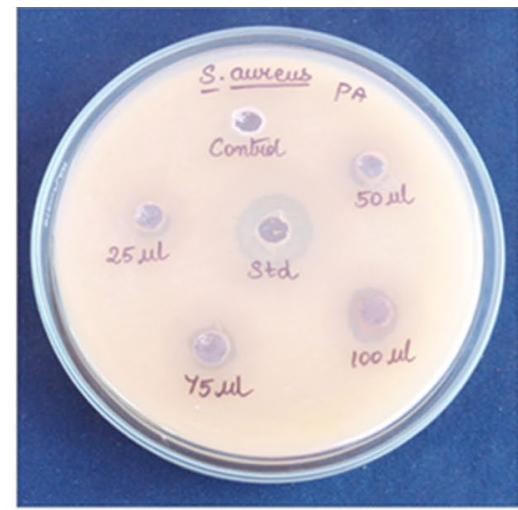

(b)

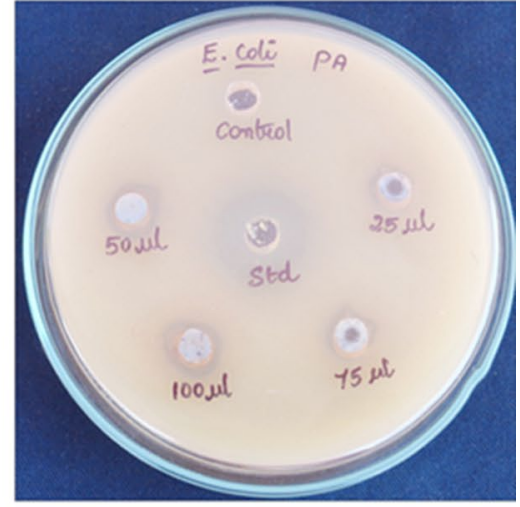

(d)

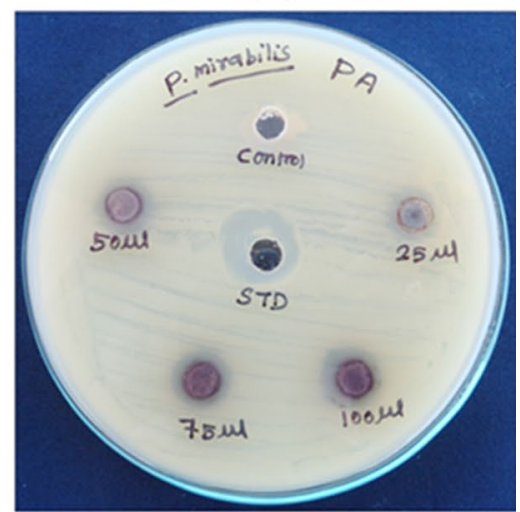

(f)

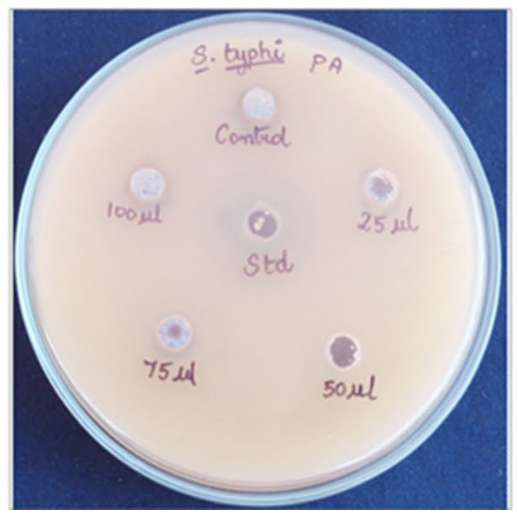

(g) 
Table 1 Antibacterial activity of Pa-AgNPs against Grampositive and Gram-negative bacterial strains

\begin{tabular}{|c|c|c|c|c|c|c|c|}
\hline \multirow[t]{2}{*}{ S. no } & \multirow[t]{2}{*}{ Test organisms } & \multicolumn{6}{|c|}{$\mathrm{ZOI}$ of $\mathrm{Pa}-\mathrm{AgNPs}$} \\
\hline & & Standard $(\mathrm{mm})$ & $\begin{array}{l}\text { Control } \\
(\mathrm{mm})\end{array}$ & $25 \mu \mathrm{l}(\mathrm{mm})$ & $50 \mu \mathrm{l}(\mathrm{mm})$ & $75 \mu \mathrm{l}(\mathrm{mm})$ & $100 \mu \mathrm{l}(\mathrm{mm})$ \\
\hline 1. & B. subtilis & $7.77 \pm 0.25$ & - & - & - & $4 \pm 0.20$ & $5 \pm 0.10$ \\
\hline 2. & S. aureus & $9.90 \pm 0.36$ & - & $4.83 \pm 0.21$ & $5.77 \pm 0.25$ & $5.97 \pm 0.06$ & $6.93 \pm 0.12$ \\
\hline 3. & S. epidermidis & $9.07 \pm 0.12$ & - & $4.93 \pm 0.21$ & $6.13 \pm 0.15$ & $5.90 \pm 0.10$ & $7.03 \pm 0.06$ \\
\hline 4. & E. coli & $13.03 \pm 0.25$ & - & $4.03 \pm 0.06$ & $6 \pm 0.20$ & $7.03 \pm 0.15$ & $6.97 \pm 0.06$ \\
\hline 5. & S. typhi & $11.03 \pm 0.25$ & - & $4.03 \pm 0.06$ & $4.80 \pm 0.26$ & $6.07 \pm 0.12$ & $6.93 \pm 0.12$ \\
\hline 6. & P. mirabilis & $8.07 \pm 0.12$ & - & $4.93 \pm 0.21$ & $6.10 \pm 0.10$ & $6.03 \pm 0.06$ & $6.83 \pm 0.29$ \\
\hline 7. & K. pneumoniae & $8.93 \pm 0.21$ & - & $4.03 \pm 0.15$ & $5 \pm 0.10$ & $6.03 \pm 0.06$ & $6.97 \pm 0.06$ \\
\hline
\end{tabular}

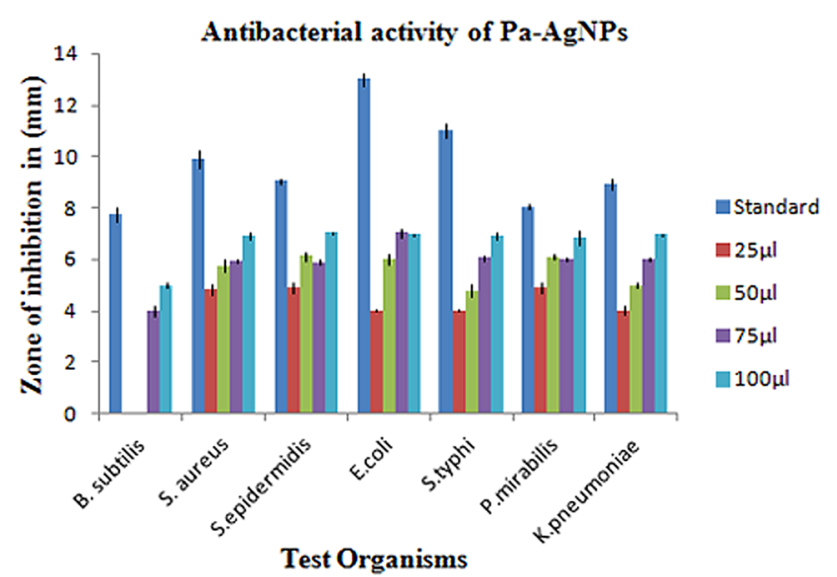

(a)

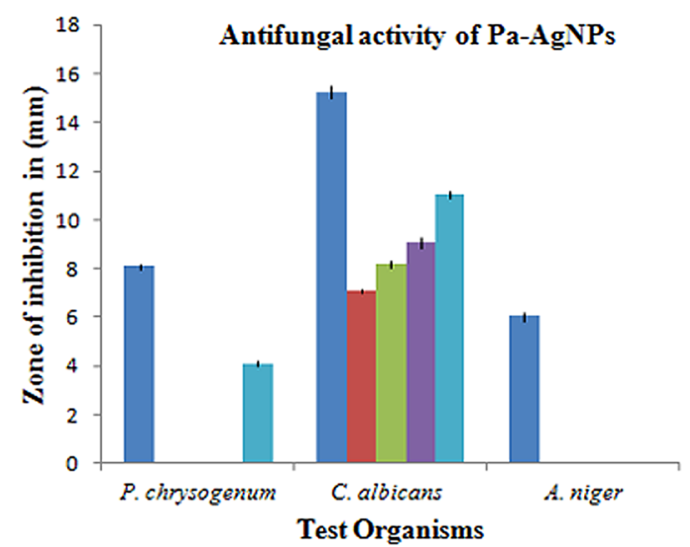

(b) property can be evaluated in in vivo models prior to human applications for the treatment of various oxidative stressrelated degenerative diseases.

\section{Conclusions}

In the present study, the endophytic bacterium $P$. anthophila isolated from the stem of $W$. indica was used for extracellular biosynthesis of AgNPs. Structural characterization showed the optimal formation of Pa-AgNPs with crystalline nature at $410 \mathrm{~nm}$ in the UV-visible spectrum, 16 to $20 \mathrm{~nm}$ size with positive surface potential. The bacterial metabolites formed a stable capping moiety around AgNPs and the elemental composition of Pa-AgNPs was also confirmed. They exhibited potential antimicrobial activity against 10 different bacterial and fungal pathogens. Higher antioxidant activity of Pa-AgNPs was also confirmed by DPPH, NO, $\mathrm{H}_{2} \mathrm{O}_{2}$, ABTS, superoxide radical scavenging assay, total antioxidant capacity assay and reducing power assay. Thus endophytic $P$. anthophila mediated biosynthesis of AgNPs prevails as an eco-friendly, cost-effective and substantial method with increased potency of applications in nanomedicine. Further, the efficiency and mechanism of Pa-AgNPs to establish as anticancer and antiviral agents will be evaluated in future to ascertain that green synthesized AgNPs are an optimistic therapeutic agent in the trending era of biomedicines.

Fig. 12 Graphical representation of ZOI produced by Pa-AgNPs against a Bacterial pathogens, b Fungal pathogens 
Fig. 13 Antifungal activity of Pa-AgNPs against a $P$. chrysogenum, b C. Albicans, $\mathbf{c}$ A. niger

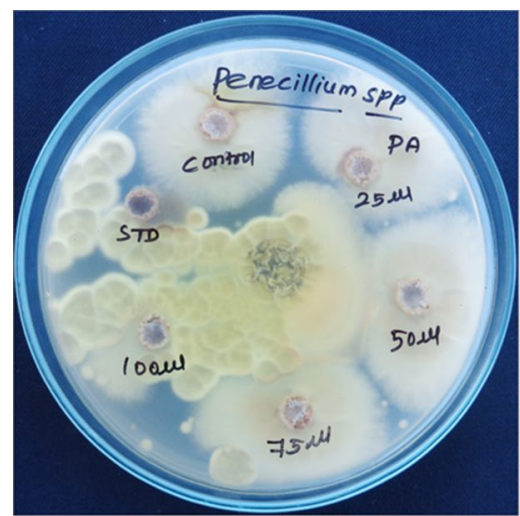

(a)

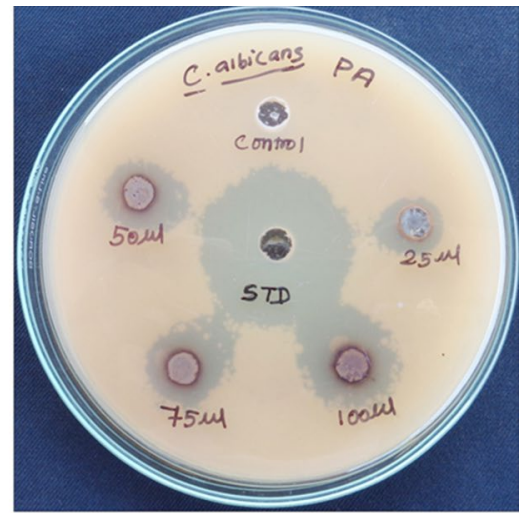

(b)

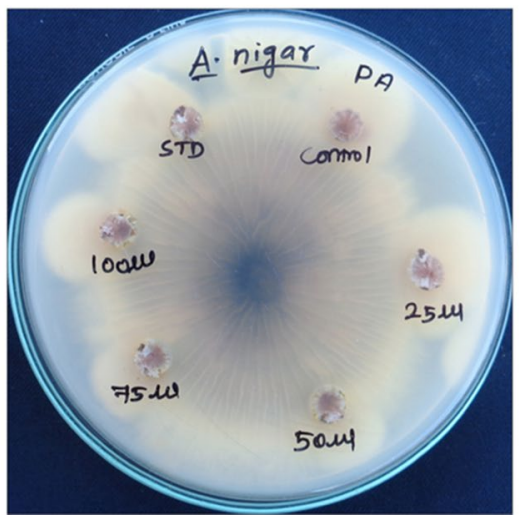

(c)

Table 2 Antifungal activity of Pa-AgNPs against selected fungal strains

\begin{tabular}{llrlllll}
\hline S. no & Test organisms & \multicolumn{2}{l}{ ZOI of Pa-AgNPs } \\
\cline { 3 - 7 } & & Standard $(\mathrm{mm})$ & $\begin{array}{l}\text { Control } \\
(\mathrm{mm})\end{array}$ & $25 \mu \mathrm{l}(\mathrm{mm})$ & $50 \mu \mathrm{l}(\mathrm{mm})$ & $75 \mu \mathrm{l}(\mathrm{mm})$ & $100 \mu \mathrm{l}(\mathrm{mm})$ \\
\hline 1. & P. chrysogenum & $8.10 \pm 0.10$ & - & - & - & - & $4.10 \pm 0.10$ \\
2. & C. albicans & $15.27 \pm 0.25$ & - & $7.10 \pm 0.10$ & $8.17 \pm 0.15$ & $9.07 \pm 0.21$ & $11.03 \pm 0.15$ \\
3. & A. niger & $6.03 \pm 0.15$ & - & - & - & - & - \\
\hline
\end{tabular}
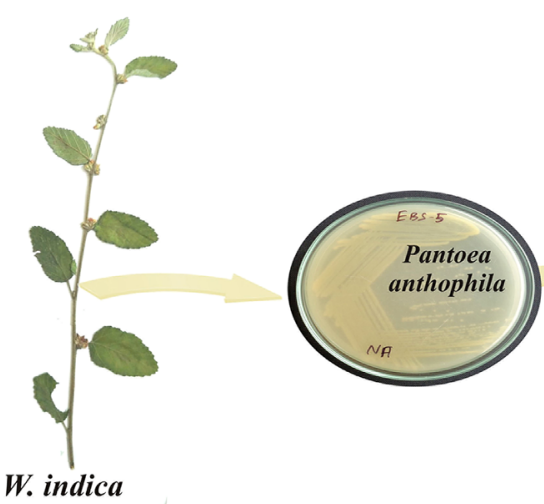

W. indica

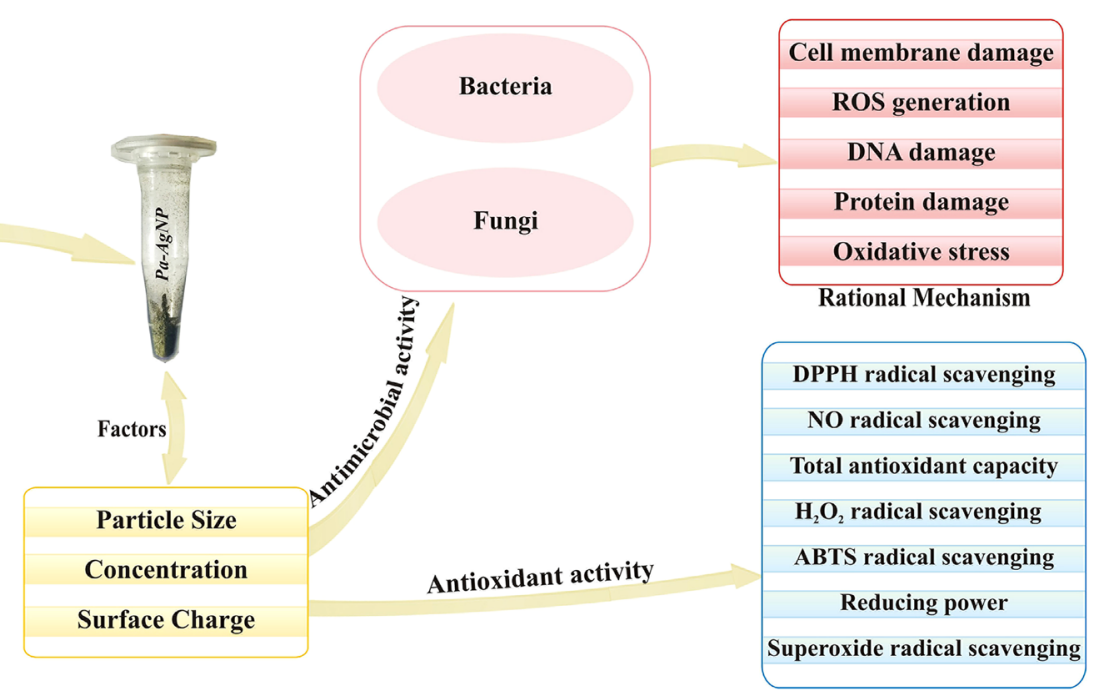

Particle Size

Concentration Surface Charge

Fig. 14 Rational mechanisms for antimicrobial activity of Pa-AgNPs 


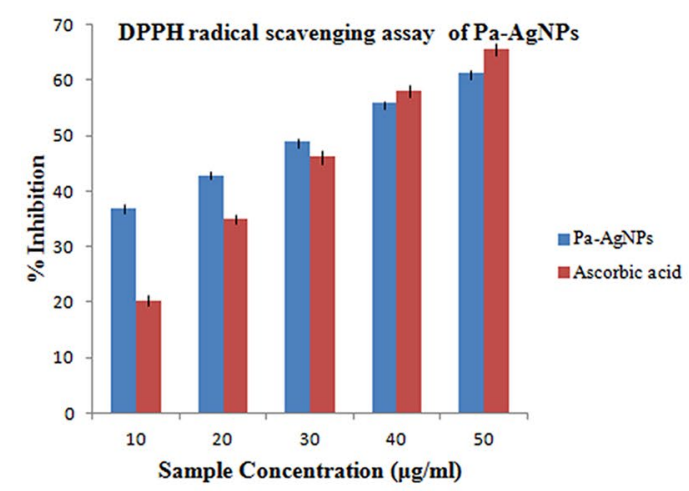

(a)

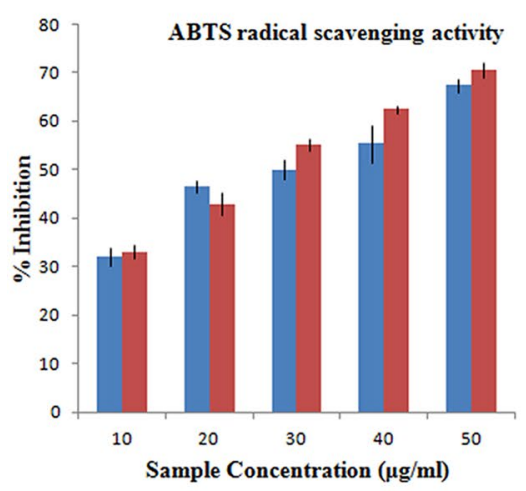

(c)

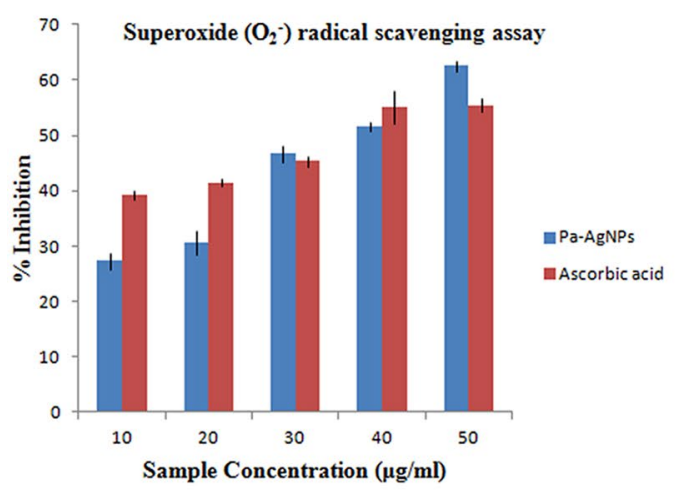

(e)

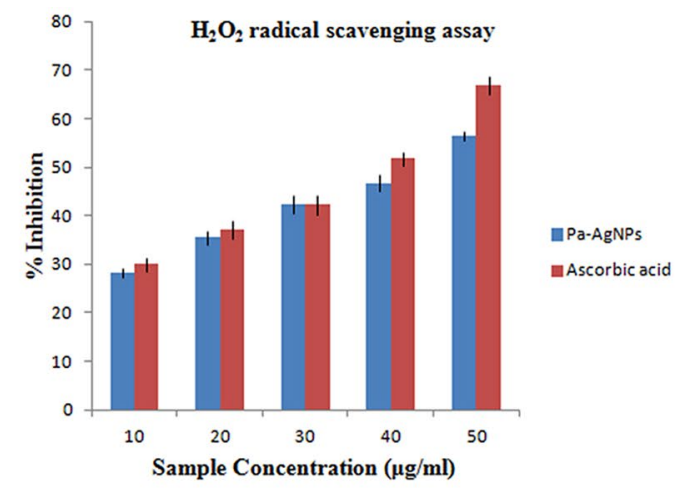

(b)

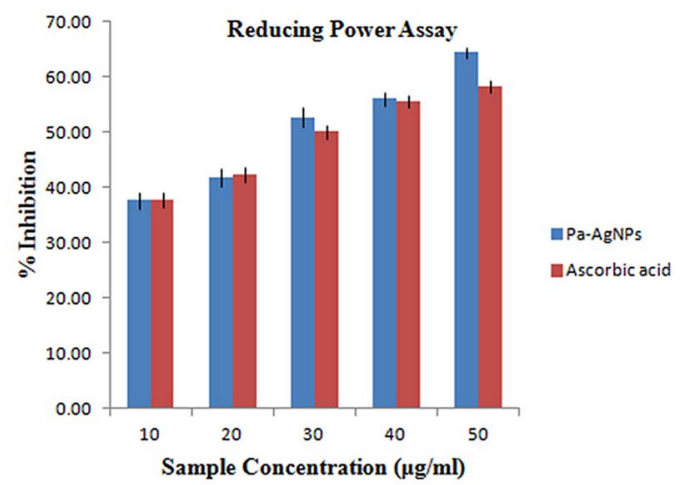

(d)

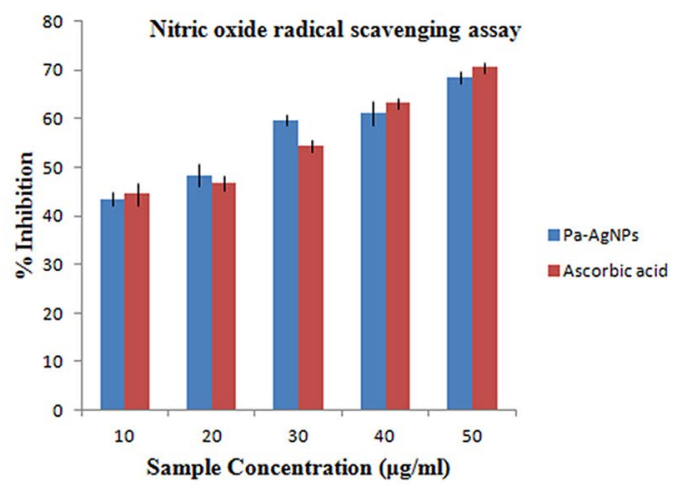

(f)

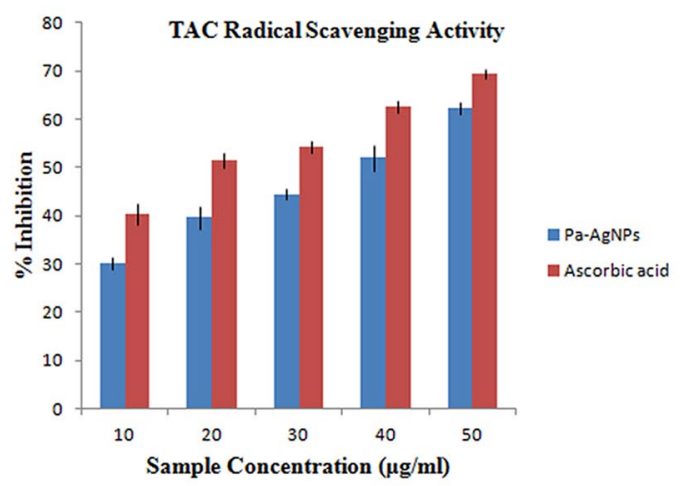

(g)

Fig. 15 Antioxidant efficacy of Pa-AgNPs a DPPH radical scavenging assay, $\mathbf{b} \mathrm{H}_{2} \mathrm{O}_{2}$ radical scavenging assay, $\mathbf{c}$ ABTS radical scavenging assay, d Reducing power assay, e Superoxide radical scavenging assay, $\mathbf{f}$ NO radical scavenging assay, $\mathbf{g}$ Total antioxidant capacity assay 
Table 3 Antioxidant activity of Pa-AgNPs

\begin{tabular}{llll}
\hline S. no & Parameters & \multicolumn{2}{l}{$\mathrm{IC}_{50}$ value $(\mu \mathrm{g} / \mathrm{ml})$} \\
\cline { 3 - 4 } & & Pa-AgNPs & Ascorbic acid \\
\hline 1. & DPPH radical scavenging assay & $31.29 \pm 0.73$ & $34.83 \pm 0.32$ \\
2. & NO radical scavenging assay & $19.83 \pm 1.57$ & $21.36 \pm 1.75$ \\
3. & Total antioxidant capacity assay & $35.64 \pm 0.94$ & $21.78 \pm 2.22$ \\
4. & $\mathrm{H}_{2} \mathrm{O}_{2}$ radical scavenging assay & $42.07 \pm 1.30$ & $34.94 \pm 0.15$ \\
5. & ABTS radical scavenging assay & $29.70 \pm 2.26$ & $26.96 \pm 0.15$ \\
6. & Reducing power assay & $29.10 \pm 0.82$ & $32.11 \pm 0.63$ \\
7. & Superoxide radical scavenging & $36.80 \pm 0.63$ & $35.76 \pm 1.56$ \\
& $\quad$ assay & & \\
\hline
\end{tabular}

Acknowledgements The authors gratefully acknowledge the Department of Biotechnology, Vinayaka Mission's Kirupananda Variyar Engineering College, Salem and Acme ProGen Biotech (India) Private Limited, Salem for providing the essential facilities to carry out the research.

Author Contributions $\mathrm{CN}$ had collected all the literature, samples and undergone the research work, analyzed, and prepared the complete manuscript under the guidance of MS, who has also critically reviewed the article for improvement. All authors have read and approved the final manuscript.

Funding No funding was received for conducting this study.

Data Availability All data generated or analyzed during this study are available upon request.

\section{Declarations}

Conflict of interest The authors declare that there are no Competing interests.

Research Involving Human and Animal Rights This article does not contain any studies with human participants or animals performed by the authors.

\section{References}

1. A.V. Ivanov, B. Bartosch, M.G. Isaguliants, Oxid. Med. Cell Longev. (2017). https://doi.org/10.1155/2017/3496043

2. P. Gupta, S.P. Authimoolam, J.Z. Hilt, T.D. Dziubla, Actabiomaterialia. (2015). https://doi.org/10.1016/j.actbio.2015.08.039

3. Y.Y. Lim, T.T. Lim, J.J. Tee, Food Chem. (2007). https://doi.org/ 10.1016/j.foodchem.2006.08.038

4. M.A. Anagnostopoulou, P. Kefalas, V.P. Papageorgiou, A.N. Assimopoulou, D. Boskou, Food Chem. (2006). https://doi.org/ 10.1016/j.foodchem.2004.09.047

5. A.K. Verma, J. Pharm. Res. 8, 7 (2014)

6. S. Ahmed, M. Ahmad, B.L. Swami, S. Ikram, J. Adv. Res. (2016). https://doi.org/10.1016/j.jare.2015.02.007

7. N. Saifuddin, C.W. Wong, A.A. Yasumira, J. Chem. 6, 1 (2009)

8. L. Wang, C. Hu, L. Shao, Int. J. Nanomed. (2017). https://doi.org/ 10.2147/IJN.S121956

9. S. Pandey, G.K. Goswami, K.K. Nanda, Sci. Rep. (2013). https:// doi.org/10.1038/srep02082
10. S. Pandey, K.K. Nanda, ACS Sens. (2016). https://doi.org/10. 1021/acssensors.5b00013

11. S. Pandey, J.Y. Do, J. Kim, M. Kang, Carbohydr. Polym. (2020). https://doi.org/10.1016/j.carbpol.2019.115597

12. L.S. Nair, C.T. Laurencin, J. Biomed. Nanotech. (2007). https:// doi.org/10.1166/jbn.2007.041

13. J.K. Patra, K.H. Baek, Front Microbiol. (2017). https://doi.org/10. 3389/fmicb.2017.00167

14. S. Coe, W.K. Woo, M. Bawendi, V. Bulović, Nature (2002). https://doi.org/10.1038/nature01217

15. M. Bruchez, M. Moronne, P. Gin, S. Weiss, A.P. Alivisatos, Science (1998). https://doi.org/10.1126/science.281.5385.2013

16. P.K. Singh, K. Bhardwaj, P. Dubey, A. Prabhune, RSC Adv. (2015). https://doi.org/10.1039/C4RA17233G

17. A. Mishra, N.K. Kaushik, M. Sardar, D. Sahal, Colloid Surf. B (2013). https://doi.org/10.1016/j.colsurfb.2013.06.036

18. R.N. Krishnaraj, S. Berchmans, RSC Adv. (2013). https://doi.org/ 10.1039/C3RA41246F

19. V. Castro-Aceituno, S. Ahn, S.Y. Simu, P. Singh, R. Mathiyalagan, H.A. Lee, D.C. Yang, Biomed. Pharmacother. (2016). https://doi. org/10.1016/j.biopha.2016.09.016

20. C. Rigo, L. Ferroni, I. Tocco, M. Roman, I. Munivrana, C. Gardin, W.R. Cairns, V. Vindigni, B. Azzena, C. Barbante, B. Zavan, Int. J. Mol. Sci. (2013). https://doi.org/10.3390/ijms 14034817

21. P.V. Baptista, M.P. McCusker, A. Carvalho, D.A. Ferreira, N.M. Mohan, M. Martins, A.R. Fernandes, Front Microbiol. (2018). https://doi.org/10.3389/fmicb.2018.01441

22. L. Wei, J. Lu, H. Xu, A. Patel, Z.S. Chen, G. Chen, Drug Discov. Today (2015). https://doi.org/10.1016/j.drudis.2014.11.014

23. A. Nazem, G.A. Mansoori, J. Alzheimer's Dis. (2008). https://doi. org/10.3233/JAD-2008-13210

24. N. Hari, T.K. Thomas, A.J. Nair, J. Nanosci. (2014). https://doi. org/10.1155/2014/201482

25. J.C. Chen, Z.H. Lin, X.X. Ma, Lett. Appl. Microbiol. (2003). https://doi.org/10.1046/j.1472-765X.2003.01348.x

26. A. Ahmad, P. Mukherjee, S. Senapati, D. Mandal, I.M. Khan, R. Kumar, M. Sastry, Colloid Surf. B. (2003). https://doi.org/10. 1016/S0927-7765(02)00174-1

27. A. Rónavári, D. Kovács, N. Igaz, C. Vágvölgyi, I.M. Boros, Z. Kónya, I. Pfeiffer, M. Kiricsi, Int. J. Nanomed. (2017). https://doi. org/10.2147/IJN.S122842

28. O.S. Koma, O.A. Fatokun, O.A. Theophilus, Biomed. Sci. (2017). https://doi.org/10.11648/j.bs.20170305.11

29. Y. Musa, M. Musah, H. Yerima, N.B. Erena, J. Adv. Res. Appl. Sci. 3, 4 (2016)

30. C. Nirmala, M. Sridevi, Future J. Pharm. Sci. (2021). https://doi. org/10.1186/s43094-020-00174-3

31. L.S. Devi, S.R. Joshi, J. Microsc. Ultrastruct. (2015). https://doi. org/10.1016/j.jmau.2014.10.004

32. T. Monowar, M. Rahman, S.J. Bhore, G. Raju, K.V. Sathasivam, Mole (2018). https://doi.org/10.3390/molecules23123220

33. K. Kalimuthu, R.S. Babu, D. Venkataraman, M. Bilal, S. Gurunathan, Colloid Surf. B (2008). https://doi.org/10.1016/j.colsurfb. 2008.02.018

34. V.L. Das, R. Thomas, R.T. Varghese, E.V. Soniya, J. Mathew, E.K. Radhakrishnan, 3 Biotech. (2014). https://doi.org/10.1007/ s13205-013-0130-8

35. T. Singh, K. Jyoti, A. Patnaik, A. Singh, R. Chauhan, S.S. Chandel, J. Genet. Eng. Biotechnol. (2017). https://doi.org/10.1016/j. jgeb.2017.04.005

36. D. Singh, V. Rathod, S. Ninganagouda, J. Hiremath, A.K. Singh, J. Mathew, Bioinorg. Chem. Appl. (2014). https://doi.org/10.1155/ 2014/408021

37. P. PatilShriniwas, Biochem. Biophys. Rep. 10, 76 (2017)

38. P.K. Jain, R.K. Agrawal, Asian J. Exp. Sci. 22, 3 (2008) 
39. S.M. Nabavi, M.A. Ebrahimzadeh, S.F. Nabavi, A. Hamidinia, A.R. Bekhradnia, Pharmacology 2, 560-567 (2008)

40. P. Prieto, M. Pineda, M. Aguilar, Anal. Biochem. (1999). https:// doi.org/10.1006/abio.1999.4019

41. G.C. Yen, P.D. Duh, J. Am. Oil Chem. Soc. (1993). https://doi. org/10.1007/BF02552711

42. F. Liu, V.E. Ooi, S.T. Chang, Life Sci. (1997). https://doi.org/10. 1016/S0024-3205(97)00004-0

43. W. Wrótniak-Drzewiecka, S. Gaikwad, D. Laskowski, H. Dahm, J. Niedojadło, A. Gade, M. Rai, Austin J. Biotechnol. Bioeng. 1, 1 (2014)

44. U.T. Khatoon, G.N. Rao, M.K. Mohan, A. Ramanaviciene, A. Ramanavicius, J. Environ. Chem. Eng. (2018). https://doi.org/10. 1016/j.jece.2018.08.009

45. S.M. Attia, M.S. Abdelfatah, M.M. Mossad, J. Phys, Conf. Ser. (2017). https://doi.org/10.1088/1742-6596/869/1/012036

46. Z.A. Ali, R. Yahya, S.D. Sekaran, R. Puteh, Adv. Mater. Sci. Eng. (2016). https://doi.org/10.1155/2016/4102196

47. R.S. Prakasham, B.S. Kumar, Y.S. Kumar, G.G. Shankar, J. Microbiol. Biotechnol. (2012). https://doi.org/10.4014/jmb.1107. 07013

48. T.A. Roseline, M. Murugan, M.P. Sudhakar, K. Arunkumar, Environ Technol. Innov. (2019). https://doi.org/10.1016/j.eti.2018.10. 005

49. S. Pandey, G.K. Goswami, K.K. Nanda, Int. J. Biol. Macromol. (2012). https://doi.org/10.1016/j.ijbiomac.2012.06.033

50. B.D. Cullity, Elements of X-Ray Diffraction, 2nd edn. (AddisonWesley Publishing Company Inc, Reading, 1978).

51. M. Gnanadesigan, M. Anand, S. Ravikumar, M. Maruthupandy, V. Vijayakumar, S. Selvam, M. Dhineshkumar, A.K. Kumaraguru, Asian Pac. J. Trop. Med. (2011). https://doi.org/10.1016/S19957645(11)60197-1

52. Z.Y. Dong, M.P. NarsingRao, M. Xiao, H.F. Wang, W.N. Hozzein, W. Chen, W.J. Li, Front Microbiol. (2017). https://doi.org/10. 3389/fmicb.2017.01090

53. M. Kumari, S. Pandey, V.P. Giri, A. Bhattacharya, R. Shukla, A. Mishra, C.S. Nautiyal, Microb Pathogen. (2017). https://doi.org/ 10.3390/molecules 23123220

54. P. Devaraj, P. Kumari, C. Aarti, A. Renganathan, J. Nanotechnol. (2013). https://doi.org/10.1155/2013/598328
55. P. Banerjee, D. Nath, Nanosci. Technol. 2, 1 (2015)

56. G.A. Otunola, A.J. Afolayan, Biotechnol. Biotechnol. Equip. (2018). https://doi.org/10.1080/13102818.2018.1448301

57. X. Hu, T.J. KandasamySaravanakumar, M.H. Wang, Int. J. Nanomed. (2019). https://doi.org/10.2147/IJN.S200817

58. U.T. Khatoon, G.N. Rao, K.M. Mohan, A. Ramanaviciene, A. Ramanavicius, Vacuum (2017). https://doi.org/10.1016/j.vacuum. 2017.10.003

59. C. Levard, E.M. Hotze, G.V. Lowry, G.E. Brown Jr., Environ. Sci. Technol. (2012). https://doi.org/10.1021/es2037405

60. S. Pandey, C.D. Klerk, J. Kim, M. Kang, E. Fosso-Kankeu, Polymers (2020). https://doi.org/10.3390/polym12061418

61. S. Pandey, J. Ramontja, Int. J. Biol. (2016). https://doi.org/10. 1016/j.ijbiomac.2016.09.033

62. A.K. Mishra, K.N. Tiwari, R. Saini, P. Kumar, S.K. Mishra, V.B. Yadav, G. Nath, J. Inorg. Organomet. Polym. (2020). https://doi. org/10.1007/s10904-019-01392-w

63. V.R. Netala, V.S. Kotakadi, P. Bobbu, S.A. Gaddam, V. Tartte, 3 Biotech. (2016). https://doi.org/10.1007/s13205-016-0433-7

64. S. Bhakya, S. Muthukrishnan, M. Sukumaran, M. Muthukumar, Appl. Nanosci. (2016). https://doi.org/10.1007/ s13204-015-0473-z

65. B. Hemashekhar, C. Chandrappa, M. Govindappa, N. Chandrasekhar, N. Ganganagappa, Y. Ramachandra, Int. J. Eng. Res. Appl. (2017). https://doi.org/10.9790/9622-0708011724.14

66. C.H. Ramamurthy, M. Padma, R. Mareeswaran, A. Suyavaran, M.S. Kumar, K. Premkumar, C. Thirunavukkarasu, Colloids Surf. B. (2013). https://doi.org/10.1016/j.colsurfb.2012.09.025

67. A.K. Keshari, R. Srivastava, P. Singh, V.B. Yadav, G. Nath, J. Ayurveda Integr. Med. (2020). https://doi.org/10.1016/j.jaim. 2017.11.003

68. C.P. Chandrappa, M. Govindappa, N. Chandrasekar, S. Sarkar, S. Ooha, R. Channabasava, Adv. Nat. Sci. Nanosci. (2016). https:// doi.org/10.1088/2043-6262/7/2/025016

Publisher's Note Springer Nature remains neutral with regard to jurisdictional claims in published maps and institutional affiliations. 